\title{
AT-I 0 I, a small molecule inhibitor of anti-apoptotic Bcl-2 family members, activates the SAPK/JNK pathway and enhances radiation-induced apoptosis
}

\author{
Shuraila F Zerp ${ }^{1}$, Rianne Stoter ${ }^{2}$, Gitta Kuipers², Dajun Yang3, \\ Marc E Lippman ${ }^{4}$, Wim J van Blitterswijk ${ }^{1}$, Harry Bartelink ${ }^{1}$, \\ Rogier Rooswinkel ${ }^{5}$, Vincent Lafleur ${ }^{2}$ and Marcel Verheij ${ }^{* 1,2}$
}

\begin{abstract}
Address: ${ }^{1}$ Department of Radiation Oncology, The Netherlands Cancer Institute - Antoni van Leeuwenhoek Hospital, Amsterdam, The Netherlands, ${ }^{2}$ Department of Radiation Oncology, VU University Medical Center, Amsterdam, The Netherlands, ${ }^{3}$ Ascenta Therapeutics, Inc., Malvern, Pennsylvania, USA, ${ }^{4}$ Department of Internal Medicine, University of Michigan Health System, Ann Arbor, Michigan, USA and ${ }^{5}$ Division of Immunology, The Netherlands Cancer Institute - Antoni van Leeuwenhoek Hospital, Amsterdam, The Netherlands

Email: Shuraila F Zerp - s.zerp@nki.nl; Rianne Stoter - tr.stoter@vumc.nl; Gitta Kuipers - gk.kuipers@vumc.nl;

Dajun Yang - dyang@Ascenta.com; Marc E Lippman - lippmanm@med.umich.edu; Wim J van Blitterswijk - w.v.blitterswijk@nki.nl; Harry Bartelink - h.bartelink@nki.nl; Rogier Rooswinkel -r.rooswinkel@nki.nl; Vincent Lafleur - mvm.lafleur@vumc.nl;

Marcel Verheij* - m.verheij@nki.nl

* Corresponding author
\end{abstract}

Published: 23 October 2009

Radiation Oncology 2009, 4:47 doi:10.1 186/1748-7/7X-4-47

This article is available from: http://www.ro-journal.com/content/4/1/47

(c) 2009 Zerp et al; licensee BioMed Central Ltd.

This is an Open Access article distributed under the terms of the Creative Commons Attribution License (http://creativecommons.org/licenses/by/2.0), which permits unrestricted use, distribution, and reproduction in any medium, provided the original work is properly cited.

\begin{abstract}
Background: Gossypol, a naturally occurring polyphenolic compound has been identified as a small molecule inhibitor of anti-apoptotic Bcl-2 family proteins. It induces apoptosis in a wide range of tumor cell lines and enhances chemotherapy- and radiation-induced cytotoxicity both in vitro and in vivo. $\mathrm{Bcl}-2$ and related proteins are important inhibitors of apoptosis and frequently overexpressed in human tumors. Increased levels of these proteins confer radioand chemoresistance and may be associated with poor prognosis. Consequently, inhibition of the anti-apoptotic functions of $\mathrm{Bcl}-2$ family members represents a promising strategy to overcome resistance to anticancer therapies.
\end{abstract}

Methods: We tested the effect of (-)-gossypol, also denominated as AT-I0I, radiation and the combination of both on apoptosis induction in human leukemic cells, Jurkat $T$ and U937. Because activation of the SAPK/JNK pathway is important for apoptosis induction by many different stress stimuli, and Bcl- $X_{L}$ is known to inhibit activation of SAPK/JNK, we also investigated the role of this signaling cascade in AT-I0I-induced apoptosis using a pharmacologic and genetic approach.

Results: AT- $10 \mathrm{I}$ induced apoptosis in a time- and dose-dependent fashion, with $\mathrm{ED}_{50}$ values of 1.9 and $2.4 \mu \mathrm{M}$ in Jurkat T and U937 cells, respectively. Isobolographic analysis revealed a synergistic interaction between AT-10I and radiation, which also appeared to be sequence-dependent. Like radiation, AT-IOI activated SAPK/JNK which was blocked by the kinase inhibitor SP600 125. In cells overexpressing a dominant-negative mutant of c-Jun, AT-I0I-induced apoptosis was significantly reduced.

Conclusion: Our data show that AT-IOI strongly enhances radiation-induced apoptosis in human leukemic cells and indicate a requirement for the SAPK/JNK pathway in AT-I0I-induced apoptosis. This type of apoptosis modulation may overcome treatment resistance and lead to the development of new effective combination therapies. 


\section{Background}

Modulation of apoptosis sensitivity has emerged as a promising strategy to increase tumor cell kill [1]. Apoptosis or programmed cell death is a characteristic mode of cell destruction and represents an important regulatory mechanism for removing abundant and unwanted cells during embryonic development, growth, differentiation and normal cell turnover. Radiation and most chemotherapeutic drugs induce apoptosis in a time- and dosedependent fashion. Failure to eliminate cells that have been exposed to mutagenic agents by apoptosis has been associated with the development of cancer and resistance to anticancer therapy. Indeed, several oncogenes mediate their effects by interfering with apoptotic signaling or by modulation of the apoptotic threshold. Bcl-2 and Bcl- $\mathrm{X}_{\mathrm{L}}$ are important inhibitors of apoptosis and frequently overexpressed in a variety of human tumors [2-7]. Increased levels of $\mathrm{Bcl}-2$ and $\mathrm{Bcl}-\mathrm{X}_{\mathrm{L}}$ have been associated with radioand chemoresistance and poor clinical outcome in various types of cancer [8-12]. In fact, among all genes studied to date in the NCI's panel of 60 human tumor cell lines, $\mathrm{Bcl}-\mathrm{X}_{\mathrm{L}}$ shows one of the strongest correlations with resistance to cytotoxic anticancer agents [13]. Therefore, inhibition of anti-apoptotic Bcl-2 family members represents an appealing strategy to overcome resistance to conventional anticancer therapies. In recent years, several agents targeting the Bcl-2 family proteins have been developed [14]

Gossypol has been identified as a potent inhibitor of Bcl$\mathrm{X}_{\mathrm{L}}$ and, to a lesser extent, of Bcl-2 [15]. It is a naturally occurring polyphenolic compound derived from cottonseed and was initially evaluated as an anti-fertility agent. Gossypol induces apoptosis in tumor cells with high Bcl$\mathrm{X}_{\mathrm{L}}$ and/or Bcl-2 expression levels, leaving normal cells with low expression levels (e.g. fibroblasts, keratinocytes) relatively unaffected [16]. Racemic $( \pm)$-gossypol is composed of 2 enantiomers: (+)-gossypol and (-)-gossypol (Fig. 1). (-)-gossypol, also denoted as AT-101, binds with high affinity to $\mathrm{Bcl}-\mathrm{X}_{\mathrm{L}}, \mathrm{Bcl}-2$ and $\mathrm{Mcl}-1$ [17] and is a more potent inducer of apoptosis than $(+)$-gossypol $[15,16,18]$. AT-101-induced cell death is associated with apoptosis hallmarks like Bak activation, cytochrome c release and effector caspase 3 cleavage [19].
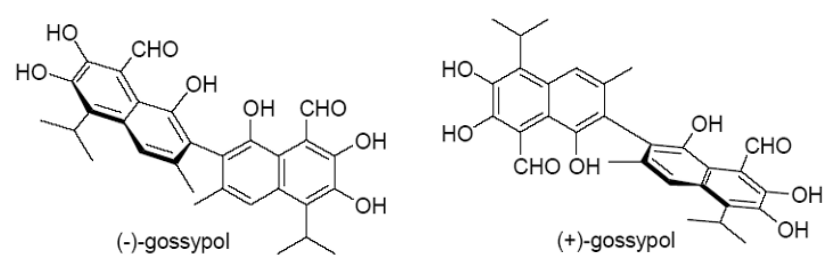

Figure I

Chemical structure of the (-) and (+) enantiomer of gossypol.
Few studies have addressed the effect of gossypol in combination with chemo- or radiotherapy [20-25]. In vitro, enhanced apoptosis and reduced clonogenicity was observed when AT-101 was combined with radiation in a prostate cancer line [22], while CHOP chemotherapy significantly enhanced AT-101-induced cytotoxicity in lymphoma cells [21]. Recent studies in multiple myeloma cell lines demonstrated synergistic toxicity with dexamethasone [25]. In head and neck squamous carcinoma cell lines the combination of stat 3 decoy and AT-101 as well as the triple combination of erlotinib, stat3 decoy and AT101 showed significant enhancement of growth inhibition [26]. Also in vivo the combined treatment of AT-101 with radiation [22] or chemotherapy [21] resulted in superior anti-tumor efficacy compared to single agent treatment. The interaction between radiation and AT-101 appeared to be sequence-dependent with radiation "sensitizing" the cells for AT-101, but not vice versa [22].

Activation of SAPK/JNK has been shown to play an important role in apoptosis induction by many stimuli, including radiation and chemotherapeutic drugs $[27,28]$. This, together with the observation that one of the major targets of AT-101, Bcl-X $\mathrm{L}$, inhibits SAPK/JNK action [29] stimulated us to investigate whether gossypol activates this pathway and whether this contributes to the pro-apoptotic effect of this novel compound.

In the present study, we describe the apoptotic effect of ionizing radiation and AT-101 in the human leukemic cell lines U937 and Jurkat T. We determined whether the combination of both treatment modalities would induce higher levels of apoptosis than after single agent treatment and characterized the type of interaction. We also tested the hypothesis that activation of the SAPK/JNK pathway is important for AT-101-induced apoptosis in these cell systems.

\section{Methods \\ Reagents}

AT-101 was provided by Ascenta Therapeutics, Inc. (Malvern, PA, USA). ( \pm )-Gossypol was purchased from SigmaAldrich. Stock solutions were prepared in dimethylsulfoxide to a concentration of $20 \mathrm{mM}$ and stored at $4^{\circ} \mathrm{C}$. Prior to use an aliquot was diluted in Dulbecco's modified Eagle's medium (DMEM; Invitrogen, Carlsbad, CA, USA). Phospho-SAPK/JNK (Thr183/Tyr185) monoclonal antibody was from Cell Signaling Technology, Inc. The SAPK/ JNK inhibitor anthrax(1,9-cd)pyrazol-692H)-one (SP600125) [30] was obtained from BIOMOL Research Laboratories (Plymouth Meeting, PA, USA) and dissolved in dimethylsulfoxide. 


\section{Cell culture and irradiation procedure}

Human monoblastic leukemia cells (U937) and the human T lymphoid leukemic Jurkat cell line (J16, kindly provided by Prof. J. Borst, The Netherlands Cancer Institute, Amsterdam), both expressing $\mathrm{Bcl}-\mathrm{X}_{\mathrm{L}^{\prime}} \mathrm{Bcl}-2$ and $\mathrm{Mcl}-$ 1 (not shown) were grown at a density between $0.1 \times 10^{6}$ and $1 \times 10^{6}$ cells $/ \mathrm{ml}$ respectively in RPMI and Iscove's modified Dulbecco's medium (Invitrogen, Carlsbad, CA, USA, Paisley, Scotland), $8 \%$ heat-inactivated fetal calf serum, glutamine $(2 \mathrm{mM})$, penicillin $(50 \mathrm{U} / \mathrm{ml})$ and streptomycin $(50 \mu \mathrm{g} / \mathrm{ml})$. U937 cells stably transfected with TAM-67 (U937/TAM-67 cells; a kind gift from dr. M.J. Birrer, National Cancer Institute, Rockville, Maryland) [31]. In selected experiments 2 human head and neck squamous cell carcinoma lines were used (VU-SCC-OE and UM-SCC-11B). These cell lines were grown in DMEM supplemented with $8 \%$ heat-inactivated fetal calf serum, glutamine $(2 \mathrm{mM})$, penicillin $(50 \mathrm{U} / \mathrm{ml})$ and streptomycin $(50 \mu \mathrm{g} / \mathrm{ml})$. For irradiation experiments, cells were exposed to gamma rays from a ${ }^{137} \mathrm{Cs}$ radiation source (Von Gahlen B.V., Didam, The Netherlands) at an absorbed dose rate of approximately $1 \mathrm{~Gy} / \mathrm{min}$. Control cells were sham-irradiated.

\section{Apoptosis assays}

Apoptosis was determined by either staining with the DNA-binding fluorochrome bisbenzimide (Hoechst 33258, Sigma) to detect morphological nuclear changes or by propidium iodide staining and FACScan analysis to determine the percentage of subdiploid apoptotic nuclei. For the bisbenzimide staining, cells were washed once with PBS and resuspended in $50 \mu \mathrm{l}$ of $3.7 \%$ paraformaldehyde. After $10 \mathrm{~min}$ at room temperature, the fixative was removed and the cells were resuspended in $15 \mu$ l of PBS containing $16 \mu \mathrm{g} / \mathrm{ml}$ bisbenzimide. Following $15 \mathrm{~min}$ incubation, a $10 \mu \mathrm{l}$ aliquot was placed on a glass slide, and 500 cells per slide were scored in duplicate for the incidence of apoptotic nuclear changes under a Olympus AH2-RFL fluorescence microscope using a UV1 exciter filter. For the propidium iodide staining, cells were seeded at $2 \times 10^{6}$ cells/ml, $200 \mu \mathrm{l} /$ well in round-bottomed, 96well microtiter plates. Cells were lysed in $200 \mu \mathrm{l} \mathrm{Nicoletti}$ Buffer $(0.1 \%$ sodium citrate, $0.1 \%$ Triton X-100, and 50 $\mu \mathrm{g} / \mathrm{ml}$ propidium iodide) and the percentage apoptotic nuclei, recognized by their subdiploid DNA content, was determined on a FACScan (Becton Dickinson, San Jose, CA) using Lysys II software.

\section{MTT assay}

Cells were grown and treated in 96 well flat-bottomed plates. Cell survival was measured by spectrophotometrical quantification of the formation of blue formazan crystals which are formed when mitochondrial dehydrogenases in viable cells reduce 3-(4,5-dimethylthiazol-2-yl)-2,5-diphenyltetrazolium bromide (MTT;
Sigma). To this end, treated cells were supplemented with $20 \mu \mathrm{l}$ of MTT solution ( $5 \mathrm{mg} / \mathrm{ml}$ ). After 15-30 min of incubation at $37^{\circ} \mathrm{C}$ the plates were centrifuged and the supernatant discarded. Formazan crystals were dissolved in 100 $\mu \mathrm{l}$ DMSO. Absorbance at $595 \mathrm{~nm}$ was measured using a Victor 2 absorbance reader (Perkin Elmer GMI, Inc, MN, USA).

\section{Western blotting}

Western blot analysis was performed to detect activated SAPK/JNK. Cells were washed, replenished with serum free medium and left overnight. Subsequently, the cultures were treated with increasing doses of radiation and/ or AT-101, washed and lysed in Triton lysis buffer $(20 \mathrm{mM}$ HEPES (pH 7.4), 2 mM EGTA, 50 mM, $\beta$-glycerophosphate, $1 \%$ Triton X-100, $2.5 \mathrm{mM} \mathrm{MgCl}_{2}, 1 \mathrm{mM} \mathrm{NA}_{3} \mathrm{VO}_{4}, 5$ $\mu \mathrm{M}$ leupeptin, $2.5 \mu \mathrm{M}$ aprotinin and $400 \mu \mathrm{M}$ phenylmethylsulfonyl fluoride) on ice for $15 \mathrm{~min}$. Lysates were clarified by centrifuging for $10 \mathrm{~min}$ at $3000 \mathrm{rpm}$, normalized for protein content and $80 \mu \mathrm{g}$ of total lysate was loaded on Invitrogen 4-12\% acrylamide NuPAGE novex bis-tris gels. Separated proteins were transferred to nitrocellulose membranes and blocked for $1 \mathrm{~h}$ with $5 \%(\mathrm{w} / \mathrm{v})$ Nutrilon Premium (Nutricia Zoetermeer, The Netherlands) in TBST. Blots were probed with SAPK/JNK monoclonal antibody (1:500) in 5\% Nutrilon in TBS-T. Control blots were probed with total SAPK/JNK polyclonal antibody ( $1: 1000)$ in $1 \%$ Nutrilon in TBS-T. After secondary horseradish peroxidase-conjugated antibody incubation, proteins were detected using the ECL detection system (GE Healthcare, Buckinghamshire, UK) and exposed to Amersham Hyperfilm MP (GE Healthcare, Buckinghamshire, UK).

\section{Statistical analyses}

To characterize the interaction between ionizing radiation and gossypol the combination index (CI) was calculated and isobolographic analysis was performed. The combination index was calculated according to the classic isobologram equation described by Chou and Talalay [32]:

$$
\mathrm{CI}=(\mathrm{D})_{1} /\left(\mathrm{D}_{\mathrm{x}}\right)_{1}+(\mathrm{D})_{2} /\left(\mathrm{D}_{\mathrm{x}}\right)_{2}
$$

In this equation, $\left(D_{x}\right)_{1}$ and $\left(D_{x}\right)_{2}$ represent the doses $D_{x}$ of compounds 1 and 2 alone required to produce an effect, and $(D)_{1}$ and $(D)_{2}$ represent isoeffective doses $D$ when compounds 1 and 2 are given simultaneously. The combination index can either indicate additivity ( $\mathrm{CI}=1)$, synergism $(\mathrm{CI}<1)$ or antagonism $(\mathrm{CI}>1)$. For isobolographic analysis, full dose response curves of both gossypol and radiation were generated using Graph Pad Prism 4.0 software. From each combination effect classic isobolograms were constructed [33]. A combination point below the area of additivity indicated a synergistic interaction between both stimuli. 


\section{Results}

\section{Radiation and gossypol induce apoptosis}

In both 4937 and Jurkat T cells, radiation induced a timeand dose-dependent increase in apoptosis, measured by bisbenzimide staining and FACScan analysis, as reported previously $[27,34,35]$. The earliest morphological nuclear changes characteristic for apoptosis were detected after 6 h (not shown). Fig. 2A, B shows the dose-dependency of radiation-induced apoptosis in the two cell lines; $\mathrm{ED}_{50}$ values at $\mathrm{t}=24 \mathrm{~h}$ are presented in Table 1.

Like radiation, AT-101 induced typical morphological features of apoptosis in a time- and dose-dependent fashion (Fig. 2C, D). As expected, AT-101 was more potent than the racemic mixture, which is reflected in the difference of their respective $\mathrm{ED}_{50}$ values (Table 1). AT-101-induced apoptosis was observed from $8 \mathrm{~h}$ onwards. Both radia- tion- and AT-101-induced apoptosis was fully inhibited by the pan-caspase inhibitor Z-VAD (data not shown).

\section{Interaction between radiation and AT- $\mathrm{IO}$ I is synergistic and sequence-dependent}

To test the combined effect of both modalities, U937 and Jurkat $\mathrm{T}$ cells were irradiated with increasing doses of gamma rays (0-32 Gy) and $24 \mathrm{~h}$ later treated with different concentrations of AT-101 $(0-10 \mu \mathrm{M})$. At various time points up to $24 \mathrm{~h}$ after treatment with AT-101, apoptosis was determined by propidium iodide staining and FACScan analysis. The combination of radiation and AT-101 induced more apoptosis than radiation alone and exceeded the sum of the effects caused by the single agent treatments (Fig. 3A). To characterize the type of interaction between both treatment modalities, the Combination Indices were calculated and isobolographic analyses were performed. For these calculations data from full
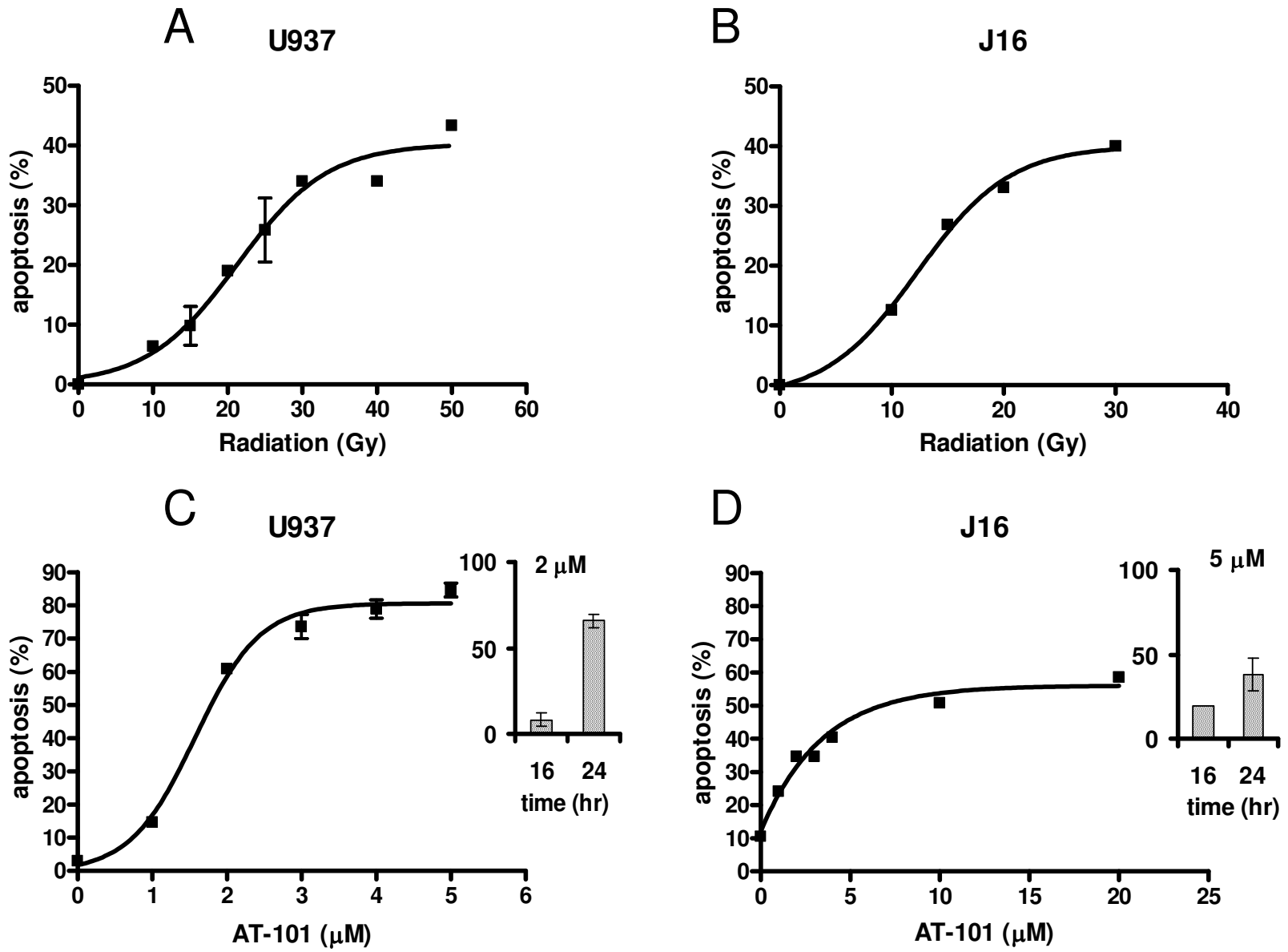

Figure 2

Dose-dependent induction of apoptosis by radiation (A, B) and AT-I OI (C, D) in human leukemic U937 (A, C) and Jurkat $\mathbf{T}$ cells (B, D). Apoptosis was quantified by FACScan analysis at $t=24 \mathrm{~h}$ after treatment. Data are presented as mean values $( \pm S D)$ from 3 independent experiments. Inserts in $C$ and $D$ show the time-dependency of AT-IOI. 
Table I: $E_{50}$ values for radiation and gossypol in human leukemic cells

\begin{tabular}{lcc}
\hline & U937 & Jurkat T \\
\hline Radiation (Gy) & 21.6 & 12.6 \\
AT-I0I $(\mu \mathrm{M})$ & 2.4 & 1.9 \\
$( \pm)$-Gossypol $(\mu \mathrm{M})$ & 5.8 & 2.4
\end{tabular}

Values are derived from full dose-response curves for each stimulus at $\mathrm{t}=24 \mathrm{~h}$; data are mean values from 2 independent experiments. dose-response curves were used. These tests revealed a clear synergistic interaction between radiation and AT101, as illustrated by a Combination Index of 0.42 and a combined effect that is projected below the area of additivity in the isobologram (Fig. 3B).

To determine whether the observed combined effect was sequence-dependent as shown by others [22], sequential treatment (radiation followed by AT-101) was compared with concurrent delivery. As shown in Fig. 3C only when radiation was applied prior to AT-101 treatment, supraadditive levels of apoptosis were found. The interval
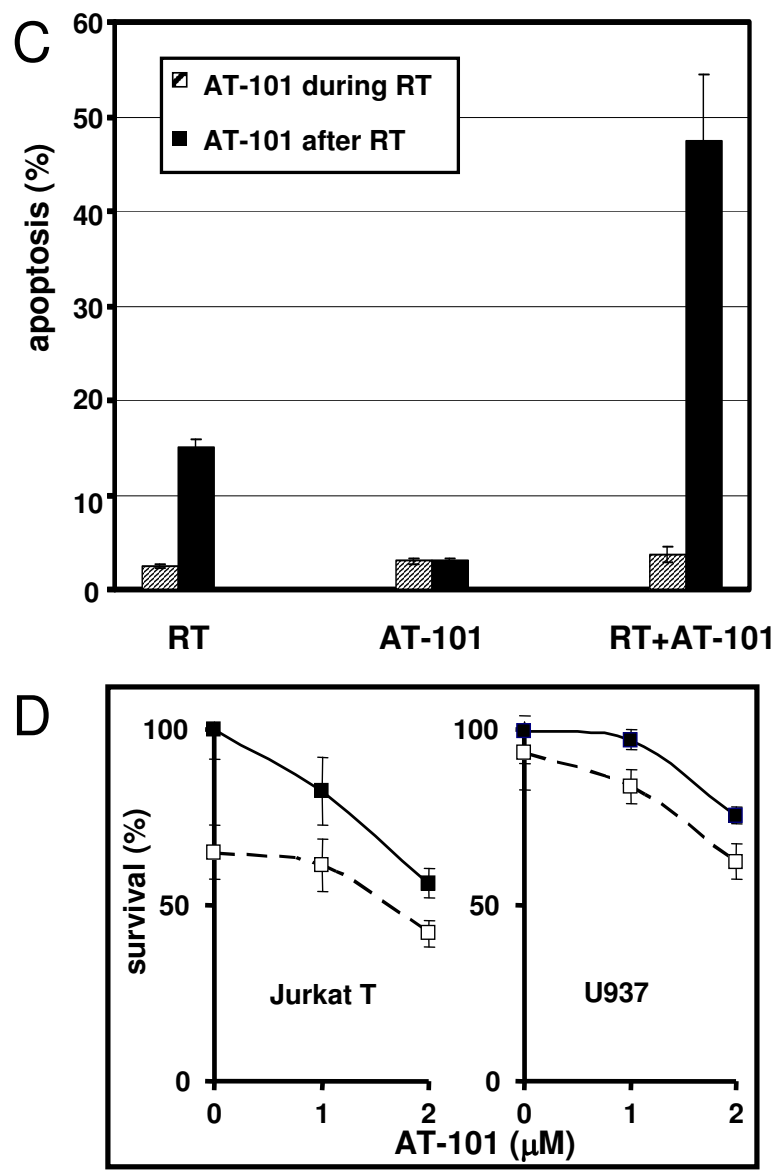

Figure 3

Synergistic and sequence-dependent interaction between radiation and AT-I0I in U937 cells. A: The combination of radiation and AT-IOI induces more apoptosis than the sum of the effects caused by the single agent treatment. Hatched bars represent the apoptotic effect by AT-IOI alone $(0-2 \mu \mathrm{M})$; black bars represent the combined effect with radiation $(8 \mathrm{~Gy})$. B: Isobolographic analysis of the combined effect of $40.6 \%$ apoptosis $(*$ in A) induced by $0.4 \mu M$ AT-I0I and 8 Gy radiation. The combination point is projected below the area of additivity, indicating synergy. The combination index for this point: $\mathrm{Cl}=$ 0.42. C: Sequence-dependency of radiation and AT- I0I. Radiation (6 Gy) and AT-IOI (I $\mu M)$ were either applied concurrently (hatched bars) or sequentially (AT-I0I $24 \mathrm{~h}$ after radiation; black bars). Apoptosis was analyzed at $\mathrm{t}=24 \mathrm{~h}$ after AT-I0I. D: MTT cell viability assays in Jurkat T and U937 cells. AT-I0I was added at the indicated concentrations (solid lines); radiation was dosed at $8 \mathrm{~Gy}$ (dashed line). Viability was determined at $\mathrm{t}=48 \mathrm{~h}$ after radiation (i.e. $24 \mathrm{~h}$ after AT-I0I). Data presented in $A, C$ and $D$ are mean values $( \pm S D)$ from 2 independent experiments. 
between both modalities should at least be $16 \mathrm{~h}$ (not shown). In contrast, concurrent treatment did not result in significant interaction which is in agreement with previous observations [22].

In addition, the effect of AT-101 and radiation on cell viability was measured using the MTT assay under conditions where we showed apoptosis induction to be synergistic. Cells were first irradiated and 24 h later treated with AT101. Cell viability was measured another $24 \mathrm{~h}$ later. As shown in Fig. 3D, AT-101 induced in a dose-dependent loss of viability, but did not further reduce cell survival after radiation.

\section{Gossypol and radiation activate the SAPKIJNK pathway}

Because SAPK/JNK-mediated signaling plays an important role in radiation-, chemotherapy- and environmental stress-induced apoptosis $[27,34]$, we tested whether gossypol also activates this signaling pathway. As shown in Fig. 4A and consistent with the apoptosis-inducing capacity, AT-101 is a more potent activator of SAPK/JNK than racemic gossypol at equimolar concentrations. SAPK/JNK is activated by AT-101 in a dose- and time-dependent manner (Fig. 4B and 4C) in a variety of human tumor cell lines, including leukemic (U937, Jurkat T) and carcinoma cells (VU-SCC-OE, UM-SCC-11B). As illustrated in Fig. $4 \mathrm{C}$, the kinetics of AT-101-induced SAPK/JNK activation varied among these different cell lines. The earliest

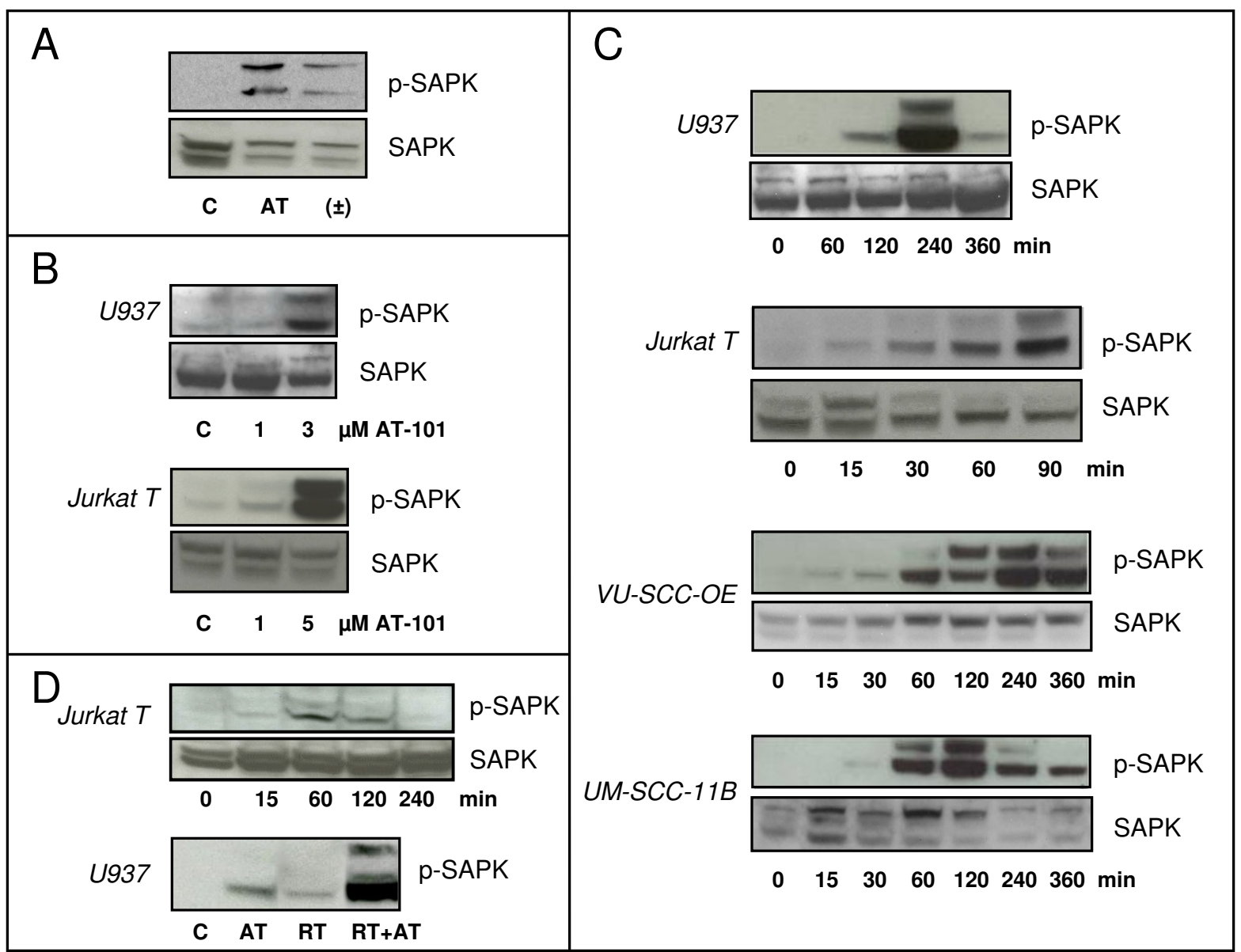

Figure 4

Gossypol and radiation activate the SAPK/JNK pathway. A: AT-I0I is a stronger activator of SAPK/JNK than racemic ( \pm )-gossypol. U937 cells were treated with equimolar concentrations of AT-I0I (5 $\mu \mathrm{M})$ and SAPK/JNK activation was analyzed at $\mathrm{t}=2 \mathrm{~h}$. (Abbreviations: $\mathrm{C}=$ control; $\mathrm{AT}=\mathrm{AT}-\mathrm{I} 0 \mathrm{I} ; \pm=( \pm)$-gossypol). B: Dose-dependent SAPK/JNK activation in U937 (upper panel) and Jurkat $T$ cells (lower panel). Cells were treated with indicated concentrations of AT-I0I and SAPK/JNK activation was analyzed at $t=2 \mathrm{~h}$. C: Kinetics of $5 \mu \mathrm{M}$ AT-I0I-induced SAPK/JNK in human leukemic (U937 and Jurkat T) and carcinoma cells (VU-SCC-OE and UM-SCC-I IB). D: Radiation (8 Gy) induces a time-dependent SAPK/JNK activation in Jurkat T cells (upper panel). In U937 cells, the combination of AT-I0I (AT; $5 \mu \mathrm{M}$ ) and radiation (RT; I0 Gy) induces a stronger activation of SAPK/JNK at $\mathrm{t}=2 \mathrm{~h}$ than single modality treatment (lower panel). 
response was observed around $15 \mathrm{~min}$. after treatment. Fig. 4D shows the time-dependent activation of SAPK/ JNK by radiation in Jurkat $T$ cells and illustrates the strongly enhanced SAPK/JNK response after combined treatment with radiation and AT-101 in U937 cells.

To assess the role of the SAPK/JNK pathway in AT-101induced apoptosis, we used the kinase inhibitor SP600125 [30] and the c-Jun dominant-negative deletion mutant TAM-67 [31] in U937 cells. As shown in Fig. 5A, SP600125 inhibited AT-101-induced SAPK/JNK activation in both cell types studied, while the compound itself had no effect. Treatment with SP600125 also significantly reduced AT-101-induced apoptosis (Fig. 5B). Moreover, in U937 cells stably expressing the dominant negative mutant of c-Jun, TAM-67, AT-101-induced apoptosis was significantly reduced as compared to vector-only controls. Taken together, these findings indicate a requirement for SAPK/JNK signaling in AT-101-induced apoptosis.

\section{Discussion}

Overexpression of anti-apoptotic members of the $\mathrm{Bcl}-2$ family is frequently observed in many different tumor types and has been associated with resistance to radioand chemotherapy and poor prognosis. The identification of gossypol as an orally available, potent small molecule inhibitor of several anti-apoptotic members of the Bcl-2 family provides a rationally designed strategy to overcome this resistance and improve clinical outcome. In the present studies, we investigated the effect of AT-101 on radiation-induced apoptosis in human U937 and Jurkat T leukemic cells. We demonstrated that AT-101 strongly enhanced radiation-induced apoptosis to levels that exceeded additivity, as shown by isobolographic analysis. Furthermore, activation of the SAPK/JNK pathway, which is known to mediate radiation-induced apoptosis, was found to play an important role in the cytotoxic effects of AT-101.

Proteins of the Bcl-2 family mediate mitochondrial permeability and are therefore the key regulators of the intrinsic apoptotic pathways [36]. Bcl-2 proteins contain regions of amino acid sequence similarity, known as Bcl2 homology (BH) domains. The family consists of the anti-apoptotic Bcl-2 group (such as Bcl-2, Bcl-X $\mathrm{L}^{\prime}, \mathrm{Mcl}-1$ ), the pro-apoptotic Bax group (Bax, Bak and Bok) and the pro-apoptotic BH3 domain-only group (including Bad, Bid, Noxa, Puma). Bcl-2 family members can homo- and heterodimerize. Dimerization and multimerization is essential for their function. Under normal conditions, BH3 domain-only proteins are either expressed at low levels or remain inactive in the cytoplasm. In response to a unique type of stress stimulus a $\mathrm{BH} 3$ domain-only protein is activated and translocates to the mitochondria to exert its pro-apoptotic effect. There are two models that describe how BH3 domain-only proteins work [36].
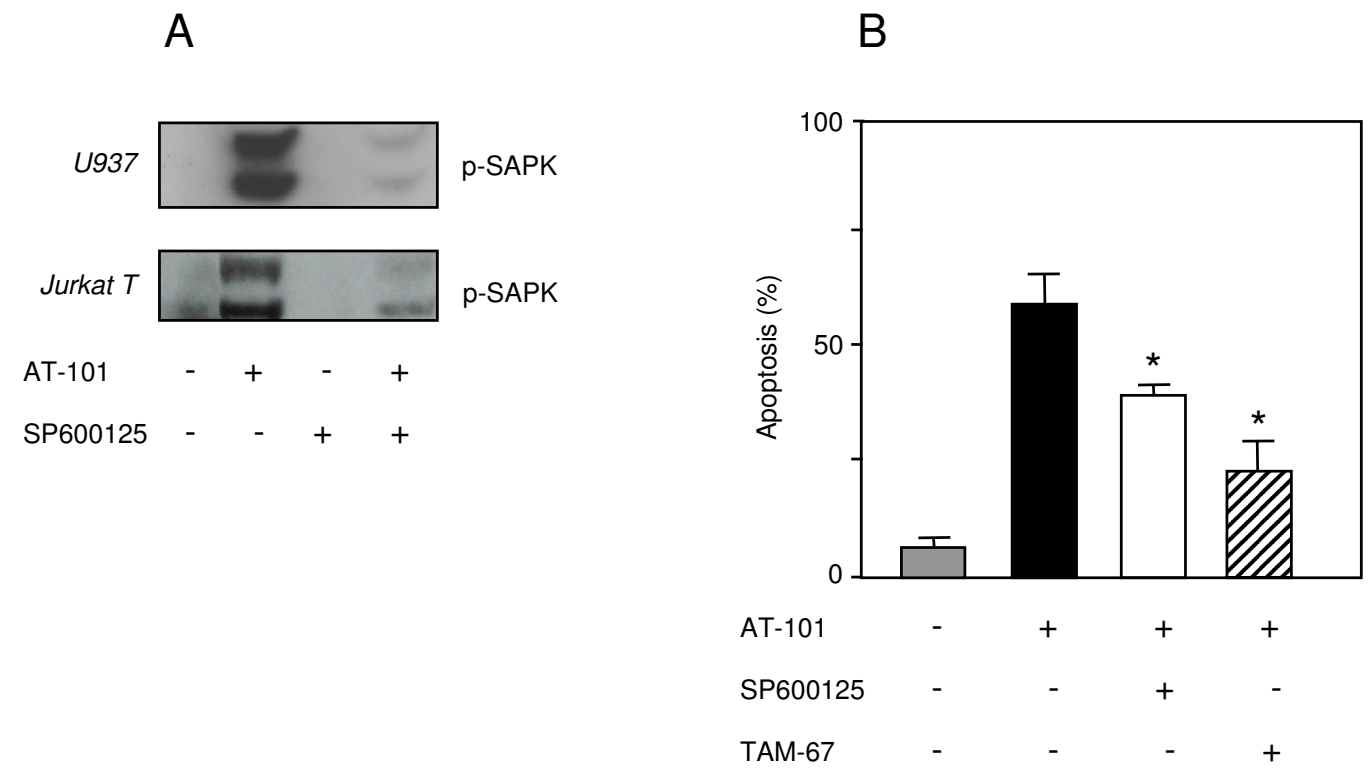

\section{Figure 5}

AT-I 0 I employs the SAPK/JNK pathway to induce apoptosis. A: AT-I0I $(5 \mu M)$ induced SAPK/JNK in U937 and Jurkat T cells can be inhibited by the SP600I 25 kinase inhibitor; $t=90 \mathrm{~min}$. B: Blockade of SAPK/JNK signaling by kinase inhibitor (SP600 I25) or dominant-negative c-Jun (TAM-67) inhibits AT-I0I (5 $\mu \mathrm{M})$-induced apoptosis at $\mathrm{t}=20 \mathrm{~h}$ in U937 cells. Data are presented as mean values $( \pm S D)$ from 2 independent experiments. ${ }^{*} p<0.005$, Student's $t$ test. 
According to one model (the direct model), they transiently interact with Bax and/or Bak to induce their homomultimerization forming a pore through which cytochrome $\mathrm{c}$ and other apoptogenic mediators are released. Inhibitory Bcl-2 family members can bind and sequester BH3 domain-only molecules, thereby preventing their pro-apoptotic interaction with Bax or Bak. According to another model, the indirect model, Bax and Bak are complexed by inhibitory Bcl-2 family members. BH3 domain-only members release Bax and Bak from such inhibition by displacing them in the complex. In this way, Bax or Bak are also free to form the homomultimer and cause mitochondrial permeabilization.

Thus, the anti-apoptotic function of $\mathrm{Bcl}-\mathrm{X}_{\mathrm{I}} / \mathrm{Bcl}-2$ is largely attributed to their ability to interact with pro-apoptotic members of the Bcl-2 family through the hydrophobic BH3 binding $\alpha$ helix, thereby preventing Bax/Bak-mediated release of cytochrome c. According to this mechanism, small molecules that interact with the BH3 binding $\alpha$ helix of Bcl- $\mathrm{X}_{\mathrm{I}} / \mathrm{Bcl}-2$ will function as $\mathrm{Bcl}-\mathrm{X}_{\mathrm{I}} / \mathrm{Bcl}-2$ antagonists and promote apoptosis. In a search for such candidates, the combination of computer modeling and in vitro fluorescence polarization displacement studies demonstrated a direct inhibition of the binding between a 16-residue Bak $\mathrm{BH} 3$ peptide and $\mathrm{Bcl}-\mathrm{X}_{\mathrm{L}}$ and $\mathrm{Bcl}-2$ by gossypol with $\mathrm{IC}_{50}$ values of $0.4 \mu \mathrm{M}$ and $10 \mu \mathrm{M}$, respectively [21]. Moreover, in silico docking studies using the 3-dimensional structure of $\mathrm{Bcl}-\mathrm{X}_{\mathrm{L}}$ predicted gossypol to bind in the deep hydrophobic groove on the surface of $\mathrm{Bcl}-\mathrm{X}_{\mathrm{L}}$ that is known to be the same site targeted by endogenous antagonists of this protein [15].

Gossypol has been shown to induce apoptosis in a variety of tumor cell lines overexpressing Bcl- $\mathrm{X}_{\mathrm{L}}$ and/or Bcl-2 $[15,16,18]$. In addition, an antitumor effect was shown in several cancer cell types [37-42]. Not many studies, however, have considered the cytotoxic effect of gossypol in combination with radio- and/or chemotherapy. In the human prostate cancer cell line PC-3, AT-101 potently enhanced radiation-induced apoptosis and growth inhibition and reduced clonogenic survival [22]. ( \pm )-Gossypol induced enhanced radiosensitivity, albeit with substantial variation in a panel of carcinoma cell lines, which primarily resulted from reduced double-strand break repair capacity [43]. In lymphoma cells the addition of CHOP chemotherapy significantly enhanced AT-101-induced cytotoxicity [21].

In the present studies we show a dose- and time-dependent induction of apoptosis by AT-101 in two human leukemic cell lines. Consistent with the observation of others $[44,45]$, the $(-)$ enantiomer was more potent in inducing apoptosis than racemic gossypol as reflected by the $\mathrm{ED}_{50}$ values. In addition, AT-101 strongly enhanced radiation-induced apoptosis in a sequence-dependent fashion. The type of interaction between both stimuli was synergistic as demonstrated by isobolographic analysis and a combination index smaller than 1.0. The nature of this enhancing effect is unknown, but is clearly the result of partially overlapping and, more importantly, partially distinct mechanisms. Radiation is known to induce the apoptotic cascade via the mitochondria-dependent intrinsic pathway where cytochrome c release is the critical event leading to caspase activation. The major mode of action of gossypol is through its interaction with the BH3binding groove in Bcl- $\mathrm{X}_{\mathrm{L}}$ and to a lesser extent in Bcl-2, thereby preventing their interaction with pro-apoptotic proteins and allowing mitochondrial permeabilization. In addition, AT- 101 has been found to bind to and inhibit the anti-apoptotic function of Mcl-1 [46]. Gossypol may also directly interact with pro-apoptotic Bcl-2 family members (Bax, Bak) and promote their multimerization which is essential for the release of cytochrome c [19].

Because gossypol has been reported to also increase radiosensitivity [22,43], we generated clonogenic survival (data not shown) and cell viability curves, but could not detect significant radiosensitization. This indicates that in the cell systems used apoptosis is the prevailing mode of cell death after the combination of radiation and AT-101. Moreover, this short term cell kill could be fully inhibited by the pan-caspase inhibitor Z-VAD.

Activation of SAPK/JNK has been shown to be essential for apoptosis induction by many types of cellular stress, including radiation and chemotherapeutic drugs $[27,47,48]$. The SAPK/JNK pathway involves sequential phosphorylation and activation of the proteins MAPK/ ERK kinase kinase 1, SAPK/ERK kinase 1, SAPK/JNK and c-Jun. There are several observations by others that prompted us to investigate the effect of gossypol on this pro-apoptotic signaling system. First, because overexpression of one of the prime targets of gossypol, $\mathrm{Bcl}-\mathrm{X}_{\mathrm{L}}$, was reported to inhibit SAPK/JNK [29], we reasoned that blocking this (and other) anti-apoptotic protein, the prodeath signaling would be restored. Second, it has been shown that SAPK/JNK translocates to the mitochondria upon irradiation and other stress factors where it phosphorylates and inactivates anti-apoptotic Bcl-2 family members, including Bcl-2, Bcl- $\mathrm{X}_{\mathrm{L}}$ and Mcl-1 [49-51]. Finally, other investigators have recently shown that $\mathrm{Bcl}-2$ antagonists like gossypol, can increase bortezomib-mediated cellular stress and SAPK/JNK activation in lymphoma cells [52]. We have previously shown that stimulation of the SAPK/JNK pathway is essential for radiation-induced apoptosis in both $\mathrm{J16}$ and U937 cells [34,46]. In our present studies, we found that in both leukemic cells and squamous cell carcinoma gossypol rapidly activated the SAPK/JNK pathway, notably with AT-101 being more 
effective than the racemic ( \pm )-gossypol. Importantly, activation of SAPK/JNK preceded the appearance of the typical morphological features of apoptosis, indicating a temporal relation between both events. The pivotal role of SAPK/JNK in AT-101-induced apoptosis was demonstrated by our experiments using the SAPK/JNK inhibitor SP600125 and the dominant-negative mutant of c-Jun. This mutant, denominated TAM-67, lacks the N-terminal transactivation domain of c-Jun, including Ser-63 and Ser73, the sites of phosphorylation and activation of the SAPK/JNK pathway [31]. SP600125 significantly inhibited AT-101-induced SAPK/JNK phosphorylation and apoptosis induction. Moreover, in cells overexpressing the TAM-67 mutant, AT-101-induced apoptosis was significantly reduced. Collectively, these data suggest that not only radiation-, but also AT-101-induced apoptosis requires a functional SAPK/JNK signaling system.

\section{Conclusion}

In summary, we have demonstrated that AT-101 strongly enhances radiation-induced apoptosis to supra-additive levels. We present evidence that activation of the SAPK/ JNK pathway significantly contributes to the apoptotic effect of AT-101. This combined approach represents an attractive strategy to overcome treatment resistance due to overexpression of anti-apoptotic Bcl-2 family members. We are currently performing preclinical proof-of-principle studies with this novel combined modality treatment in a mouse xenograft tumor model.

\section{Competing interests}

The authors declare that they have no competing interests.

\section{Authors' contributions}

SFZ carried out the apoptosis and MTT assays, Western blotting and statistical analyses and participated in the design of the study. RS carried out part of the Western blotting. GK, DY, MEL, WJB, HB and VL participated in the design of the study and analyzed data. RR carried out part of the apoptosis assays and provided supplementary results. MV conceived and designed the experiments, analyzed data and wrote the paper. All authors read and approved the final manuscript.

\section{Acknowledgements}

This work was in part financially supported by the Dutch Cancer Society (grants NKI 200I-2570 and NKI 2007-3939)

\section{References}

I. Belka C, Jendrossek V, Pruschy M, Vink S, Verheij M, Budach W: Apoptosis-modulating agents in combination with radiotherapy-current status and outlook. Int J Radiat Oncol Biol Phys 2004, 58:542-554.

2. Hellemans P, van Dam PA, Weyler J, Van Oosterom AT, Buytaert P, Van Marck E: Prognostic value of bcl-2 expression in invasive breast cancer. Br J Cancer 1995, 72:354-360.

3. Krajewski S, Krajewska M, Ehrmann J, Sikorska M, Lach B, Chatten J, Reed JC: Immunohistochemical analysis of Bcl-2, Bcl-X, Mcl-
$I$, and Bax in tumors of central and peripheral nervous system origin. Am J Pathol 1997, 150:805-8I4.

4. Olopade OI, Adeyanju MO, Safa AR, Hagos F, Mick R, Thompson CB, Recant WM: Overexpression of BCL-x protein in primary breast cancer is associated with high tumor grade and nodal metastases. Cancer J Sci Am 1997, 3:230-237.

5. Pena JC, Thompson CB, Recant W, Vokes EE, Rudin CM: Bcl-xL and $\mathrm{Bcl}-2$ expression in squamous cell carcinoma of the head and neck. Cancer 1999, 85:164-I70.

6. Schneider HJ, Sampson SA, Cunningham D, Norman AR, Andreyev $H J$, Tilsed JV, Clarke PA: Bcl-2 expression and response to chemotherapy in colorectal adenocarcinomas. $\mathrm{Br} J$ Cancer 1997, 75:427-43।.

7. Trask DK, Wolf GT, Bradford CR, Fisher SG, Devaney K, Johnson M, Singleton $\mathrm{T}$, Wicha $\mathrm{M}$ : Expression of $\mathrm{Bcl}-2$ family proteins in advanced laryngeal squamous cell carcinoma: correlation with response to chemotherapy and organ preservation. Laryngoscope 2002, I | 2:638-644.

8. Ong F, Moonen LM, Gallee MP, ten Bosch C, Zerp SF, Hart AA, Bartelink $\mathrm{H}$, Verheij M: Prognostic factors in transitional cell cancer of the bladder: an emerging role for $\mathrm{Bcl}-2$ and $\mathrm{p} 53$. Radiother Oncol 200I, 61:169-175.

9. Reed JC, Miyashita T, Takayama S, Wang HG, Sato T, Krajewski S, Aimé-Sempé C, Bodrug S, Kitada S, Hanada M: BCL-2 family proteins: regulators of cell death involved in the pathogenesis of cancer and resistance to therapy. J Cell Biochem 1996, 60:23-32.

10. Simonian PL, Grillot DA, Nunez G: Bcl-2 and Bcl-XL can differentially block chemotherapy-induced cell death. Blood 1997, 90:1208-1216.

II. Gallo O, Chiarelli I, Boddi V, Bocciolini C, Bruschini L, Porfirio B: Cumulative prognostic value of $\mathrm{p} 53$ mutations and bcl-2 protein expression in head-and-neck cancer treated by radiotherapy. Int J Cancer 1999, 84:573-579.

12. Minn A], Rudin CM, Boise LH, Thompson CB: Expression of bcl-xL can confer a multidrug resistance phenotype. Blood 1995, 86:1903-1910.

13. Amundson SA, Myers TG, Scudiero D, Kitada S, Reed JC, Fornace AJ Jr: An informatics approach identifying markers of chemosensitivity in human cancer cell lines. Cancer Res 2000, 60:610I-6II0.

14. Kang MH, Reynolds CP: Bcl-2 inhibitors: targeting mitochondrial apoptotic pathways in cancer therapy. Clin Cancer Res 2009, I 5: I| $26-1 \mid 132$

15. Kitada S, Leone M, Sareth S, Zhai D, Reed JC, Pellecchia M: Discovery, characterization, and structure-activity relationships studies of proapoptotic polyphenols targeting B-cell lymphocyte/leukemia-2 proteins. J Med Chem 2003, 46:4259-4264.

16. Oliver CL, Bauer JA, Wolter KG, Ubell ML, Narayan A, O'Connell KM, Fisher SG, Wang S, Wu X, Ji M, Carey TE, Bradford CR: In vitro effects of the $\mathrm{BH} 3$ mimetic, (-)-gossypol, on head and neck squamous cell carcinoma cells. Clin Cancer Res 2004, I0:7757-7763.

17. Zhai $D$, Jin $C$, Satterthwait $A C$, Reed JC: Comparison of chemical inhibitors of antiapoptotic Bcl-2-family proteins. Cell Death Differ 2006, 13:1419-1421.

18. Liu S, Kulp SK, Sugimoto Y, Jiang J, Chang HL, Dowd MK, Wan P, Lin YC: The (-)-enantiomer of gossypol possesses higher anticancer potency than racemic gossypol in human breast cancer. Anticancer Res 2002, 22:33-38.

19. Oliver CL, Miranda MB, Shangary S, Land S, Wang S, Johnson DE: (-)Gossypol acts directly on the mitochondria to overcome Bcl2- and $\mathrm{Bcl}-\mathbf{X}(\mathrm{L})$-mediated apoptosis resistance. Mol Cancer Ther 2005, 4:23-31.

20. Bauer JA, Trask DK, Kumar B, Los G, Castro J, Lee JS, Chen J, Wang $S$, Bradford CR, Carey TE: Reversal of cisplatin resistance with a BH3 mimetic, (-)-gossypol, in head and neck cancer cells: role of wild-type p53 and Bcl-xL. Mol Cancer Ther 2005, 4:1096-1 I04.

21. Mohammad RM, Wang S, Aboukameel A, Chen B, Wu X, Chen J, AlKatib A: Preclinical studies of a nonpeptidic small-molecule inhibitor of $\mathrm{Bcl}-2$ and $\mathrm{BCl}-\mathrm{X}(\mathrm{L})$ [(-)-gossypol] against diffuse large cell lymphoma. Mol Cancer Ther 2005, 4: I3-2I.

22. Xu L, Yang D, Wang S, Tang W, Liu M, Davis M, Chen J, Rae JM, Lawrence $T$, Lippman ME: (-)-Gossypol enhances response to radiation therapy and results in tumor regression of human prostate cancer. Mol Cancer Ther 2005, 4:197-205. 
23. Li ZM, Jiang WQ, Zhu ZY, Zhu XF, Zhou JM, Liu ZC, Yang DJ, Guang $Z Z$ : Synergistic cytotoxicity of Bcl-xL inhibitor, gossypol and chemotherapeutic agents in non-Hodgkin's lymphoma cells. Cancer Biol Ther 2007, 7:5I-60.

24. Meng Y, Li Y, Li J, Li H, Fu J, Liu Y, Liu H, Chen X: (-)Gossypol and its combination with imatinib induce apoptosis in human chronic myeloid leukemic cells. Leuk Lymphoma 2007, 48:2204-22।

25. Kline MP, Rajkumar SV, Timm MM, Kimlinger TK, Haug JL, Lust JA, Greipp PR, Kumar S: R-(-)-gossypol (AT-IOI) activates programmed cell death in multiple myeloma cells. Exp Hematol 2008, 36:568-576.

26. Boehm A, Sen M, Seethala R, Gooding WE, Freilino M, Wong SM, Wang S, Johnson DE, Grandis JR: Combined Targeting of EGFR, STAT3, and Bcl-XL Enhances Antitumor Effects in Squamous Cell Carcinoma of the Head and Neck. Mol Pharmacol 2008, 73:1632-1642.

27. Verheij M, Ruiter GA, Zerp SF, van Blitterswijk WJ, Fuks Z, Haimovitz-Friedman A, Bartelink $\mathrm{H}$ : The role of the stress-activated protein kinase (SAPK/JNK) signaling pathway in radiationinduced apoptosis. Radiother Oncol 1998, 47:225-232.

28. Zanke BW, Boudreau K, Rubie E, Winnett E, Tibbles LA, Zon L, Kyriakis J, Liu FF, Woodgett JR: The stress-activated protein kinase pathway mediates cell death following injury induced by cisplatinum, UV irradiation or heat. Curr Biol 1996, 6:606-613.

29. Pandey P, Avraham S, Place A, Kumar V, Majumder PK, Cheng K, Nakazawa A, Saxena S, Kharbanda S: Bcl-xL blocks activation of related adhesion focal tyrosine kinase/proline-rich tyrosine kinase 2 and stress-activated protein kinase/c-Jun N-terminal protein kinase in the cellular response to methylmethane sulfonate. J Biol Chem 1999, 274:86|8-8623.

30. Bennett BL, Sasaki DT, Murray BW, O'Leary EC, Sakata ST, Xu W, Leisten JC, Motiwala A, Pierce S, Satoh Y, Bhagwat SS, Manning AM, Anderson DW: SP600I25, an anthrapyrazolone inhibitor of Jun N-terminal kinase. Proc Natl Acad Sci USA 200I, 98: | $368|-| 3686$.

31. Brown PH, Alani R, Preis LH, Szabo E, Birrer MJ: Suppression of oncogene-induced transformation by a deletion mutant of $c$ jun. Oncogene 1993, 8:877-886.

32. Chou TC, Talalay P: Quantitative analysis of dose-effect relationships: the combined effects of multiple drugs or enzyme inhibitors. Adv Enzyme Regul 1984, 22:27-55.

33. Steel GG, Peckham MJ: Exploitable mechanisms in combined radiotherapy-chemotherapy: the concept of additivity. Int J Radiat Oncol Biol Phys 1979, 5:85-91.

34. Verheij M, Bose R, Lin XH, Yao B, Jarvis WD, Grant S, Birrer MJ, Szabo E, Zon LI, Kyriakis JM, Haimovitz-Friedman A, Fuks Z, Kolesnick RN: Requirement for ceramide-initiated SAPK/JNK signalling in stress-induced apoptosis. Nature 1996, 380:75-79.

35. Wissink EH, Verbrugge I, Vink SR, Schader MB, Schaefer U, Walczak $H$, Borst J, Verheij M: TRAIL enhances efficacy of radiotherapy in a $\mathbf{p} 53$ mutant, $\mathrm{Bcl}-2$ overexpressing lymphoid malignancy. Radiother Oncol 2006, 80:214-222.

36. Fletcher JI, Huang DC: Controlling the cell death mediators Bax and Bak: puzzles and conundrums. Cell Cycle 2008, 7:39-44.

37. Bushunow P, Reidenberg MM, Wasenko J, Winfield J, Lorenzo B, Lemke S, Himpler B, Corona R, Coyle T: Gossypol treatment of recurrent adult malignant gliomas. J Neurooncol I999, 43:79-86.

38. Flack MR, Pyle RG, Mullen NM, Lorenzo B, Wu YW, Knazek RA, Nisula BC, Reidenberg MM: Oral gossypol in the treatment of metastatic adrenal cancer. J Clin Endocrinol Metab 1993, 76:1019-1024

39. Van Poznak C, Seidman AD, Reidenberg MM, Moasser MM, Sklarin N, Van Zee K, Borgen P, Gollub M, Bacotti D, Yao TJ, Bloch R, Ligueros $M$, Sonenberg M, Norton L, Hudis C: Oral gossypol in the treatment of patients with refractory metastatic breast cancer: a phase I/II clinical trial. Breast Cancer Res Treat 200I, 66:239-248.

40. Zhang M, Liu H, Guo R, Ling Y, Wu X, Li B, Roller PP, Wang S, Yang $\mathrm{D}$ : Molecular mechanism of gossypol-induced cell growth inhibition and cell death of HT-29 human colon carcinoma cells. Biochem Pharmacol 2003, 66:93-103.

41. Zhang M, Liu H, Tian Z, Griffith BN, Ji M, Li QQ: Gossypol induces apoptosis in human $\mathrm{PC}-3$ prostate cancer cells by modulating caspase-dependent and caspase-independent cell death pathways. Life Sci 2007, 80:767-774.
42. Wolter KG, Wang SJ, Henson BS, Wang S, Griffith KA, Kumar B, Chen J, Carey TE, Bradford CR, D'Silva NJ: (-)-gossypol inhibits growth and promotes apoptosis of human head and neck squamous cell carcinoma in vivo. Neoplasia 2006, 8: 163-I72.

43. Kasten-Pisula U, Windhorst S, Dahm-Daphi J, Mayr G, Dikomey E: Radiosensitization of tumour cell lines by the polyphenol Gossypol results from depressed double-strand break repair and not from enhanced apoptosis. Radiother Oncol 2007, 83:296-303.

44. Shelley MD, Hartley L, Fish RG, Groundwater P, Morgan JJ, Mort D, Mason M, Evans A: Stereo-specific cytotoxic effects of gossypol enantiomers and gossypolone in tumour cell lines. Cancer Lett 1999, I35:17|-180.

45. Shelley MD, Hartley L, Groundwater PW, Fish RG: Structure-activity studies on gossypol in tumor cell lines. Anticancer Drugs 2000, II:209-216.

46. Loberg RD, McGregor N, Ying C, Sargent E, Pienta KJ: In vivo evaluation of AT-IOI (R-(-)-gossypol acetic acid) in androgenindependent growth of VCaP prostate cancer cells in combination with surgical castration. Neoplasia 2007, 9:1030-1037.

47. Ruiter GA, Zerp SF, Bartelink H, van Blitterswijk WJ, Verheij M: Alkyl-lysophospholipids activate the SAPK/JNK pathway and enhance radiation-induced apoptosis. Cancer Res 1999, 59:2457-2463.

48. Ruiter GA, Verheij M, Zerp SF, van Blitterswijk WJ: Alkyl-lysophospholipids as anticancer agents and enhancers of radiationinduced apoptosis. Int J Radiat Oncol Biol Phys 200I, 49:4I5-4I9.

49. Kharbanda S, Saxena S, Yoshida K, Pandey P, Kaneki M, Wang Q, Cheng K, Chen YN, Campbell A, Sudha T, Yuan ZM, Narula J, Weichselbaum R, Nalin C, Kufe D: Translocation of SAPK/JNK to mitochondria and interaction with $\mathrm{Bcl}-\mathrm{x}(\mathrm{L})$ in response to DNA damage. J Biol Chem 2000, 275:322-327.

50. Inoshita S, Takeda K, Hatai T, Terada Y, Sano M, Hata J, Umezawa A, Ichijo $\mathrm{H}$ : Phosphorylation and Inactivation of Myeloid Cell Leukemia I by JNK in Response to Oxidative Stress. J Biol Chem 2002, 277:43730-43734.

5I. Yamamoto K, Ichijo H, Korsmeyer SJ: BCL-2 is phosphorylated and inactivated by an ASKI/Jun $\mathrm{N}$-terminal protein kinase pathway normally activated at G(2)/M. Mol Cell Biol 1999 , 19:8469-8478.

52. Dasmahapatra G, Lembersky D, Rahmani M, Kramer L, Friedberg J, Fisher RI, Dent P, Grant S: Bcl-2 antagonists interact synergistically with bortezomib in DLBCL cells in association with JNK activation and induction of ER stress. Cancer Biol Ther 2009, 8:808-810.

\section{Publish with BioMed Central and every scientist can read your work free of charge}

"BioMed Central will be the most significant development for disseminating the results of biomedical research in our lifetime."

Sir Paul Nurse, Cancer Research UK

Your research papers will be:

- available free of charge to the entire biomedical community

- peer reviewed and published immediately upon acceptance

- cited in PubMed and archived on PubMed Central

- yours - you keep the copyright
BioMedcentral 